housing the control room, machinery and equipment rooms and the communications systems. It is anticipated that antennae the size of the " 210 " will be constructed eventually at other sites of the Deep Space Network.

\section{Electrical Biology Laboratory}

A LABORATORY for biological research for the electrical industry has been established by the Central Electricity Generating Board at Leatherhead, Surrey. The Laboratory was opened officially on May 6, 1966, by Sir Cyri Hinshelwood. It is intended to be a centre for the biological research of all kinds carried out by electricity authorities in all parts of Britain. Among the problems within the scope of the new Laboratory are the study of the growth of barnacles and mussels in power station cooling water. Mussels can detract from the operating officiency by lodging in condenser tubes, thus causing corrosion. The same tubes are ideally suitable for the growth of many other marine organisms, which must be eliminated without, at the same time, so contaminating the water as to make it a public hazard. The Laboratory is also concerned with biological problems arising from the increased temperature of water discharged from power stations. The facilities of the Laboratory will include special tank rooms for the study of freshwater invertebrates. It will have X-ray machines which will, in particular, be able to study the effect of temperature on the shipworm Teredo-a pest of wooden marine structures. It is also intiended to study the biological problems arising from the use of pulverized fuel ash in the reclamation of agricultural land.

\section{Modern History}

Is his presidential address to the Diamond Jubilee Conference of the Historical Association, Geoffrey Barraclough, Fellow of St. John's College, Cambridge, stressed that historians must offer the general public something more than technical controversies if they wished to compete against "the attractions of modern science".

Speaking on the subject "History and the Common Man", Barraclough said that the study of history has lost its sense of purpose and is suffering from what he termed a malaise; to the ordinary educated mathematician, nuclear physicist, and natural scientist, "history is a form of entertainment; . . . relaxation for the intelligent scientist or technologist who is a cut above the telly and does not take to novels". He added that there was "a sharp cleavage between history written for the public, which is not scholarly, and scholarly history which is not read by the public".

The two aspects of current historical teaching and research that Barraclough felt must change are its lack of relevance to prosent events and its fundamental postulate that history is the key to the explanation of ovents. He deplored the fact that the teaching of history was only slowly changing from the study of minute investigations of obscure details of British history to leave more time for the broader issues of European and world history.

Barraclough strongly attacked the Germanic approach that searched for the causes and motivations of events rather than their consequences. He noted that the Danish theologian Kierkegaard said that history should concern itself. with results, while motives and intentions are the business of ethics. Barraclough expressed the belief that this historical guesswork is being replaced by a more scientific approach to history, in spite of a "suicide squad fighting a stubborn rearguard action". 'This means, he added, that "historians, at last, are broaking away from their vain pre-occupation with motives and causes and surmise, and getting down to facts".

Tt will be interesting to see if this hopeful prediction is fulfilled, and, if so, whether history will becomo less entertaining in the process.
University News:

Glasgow

THE following have been appointed to chairs: H. B. Sutherland (civil engineering); Dr. I. A. Boyd (physiology); Dr. R. M. S. Smellie (biochemistry).

London

Sir Thomas Creed, principal of Queen Mary College, has been elected vice-chancellor as from September 1, for the university year 1966-67. Prof. C. T. Ingold, of Birkbeck College, has been appointed deputy vicechancellor as from September 1 for the university year 1966-67. The title of professor has been conferred on the following: Dr. R. H. Gorrill (bacteriology, in respect of his post at Guy's Hospital Medical School); Dr. E. Jean Hanson (biology, in respect of her post at King's College); Dr. C. W. Kilmister (mathematics, in respect of his post at King's College).

\section{Announcements}

DR. V. Bush was awarded the first Founders' Medal of the National Academy of Engineering during the second annual meeting of the National Academy of Engineering on April 27. The Founders' Medal was established in April 1965 to honour outstanding contributions by an engineer both to his profession and to society.

Prof. B. Edifín of Lund has been awarded the Mees Medal of the Optical Society of America for distinguished work over a period of more than thirty-five years on the light emitted by the vapours of highly ionized elements.

A symposrum on "Simulation Techniques and Languages" will be hold in Brunel College during May 10-11. Further information can be obtained from the Academic Registrar, Brunel College, Woodlands Avenue, Acton, London, W.3.

THE second international congress on "Hormonal Steroids" will be held in the University of Milan during May 23-28. Further information can be obtained from Dr. L. Martini, Istituto di Farmacologia, Via Andrea del Sarto 21, Milan.

A short course on "High Temperature Resistant Polymers" will be held at the Bradford Institute of Technology during May 13-14. Further information can be obtained from the Registrar, Bradford Institute of Technology, Bradford 7.

The fifth international congress of the precast concrete industry will be held in London during May 21-27. Further information can be obtained from the Organizing Secretary of the Congress, Terminal House, Grosvenor Gardens, London, S.W.1.

THe third annual national colloquium on "Information Retrieval" will be held in the University of Pennsylvania during May 12-13. Further information can be obtained from A. W. Speakman, E. I. du Pont Company, Centre Road Building, Wilmington, Delaware.

A symposium on "Physico-Chomical Processes in Mixed Aqueous Solvents" will be held at Bradford Instituto of Technology during May 23-24. Further information can be obtained from Dr. F. Franks, Department of Chemical Technology, Bradford Institute of Technology, Bradford 7.

A course on "Cancer Chemotherapy" will be held in the University of Texas during May 9-21. Further information can be obtained from the Division of Continuing Education, University of Texas Graduate School of Biomedical Sciences at Houston, 102 Jesse Jones Library Building, Texas Medical Center, Houston.

THE sixth international symposium on "Condensation Nuclei" will be held in Albany, New York, and University Park, Pennsylvania, during May 9-14. Further information can be obtained from the chairman of the Organizing Committee, Office of the Director, Atmospheric Scionces Research Center, State University of Now York, Post Office Box 7112, Albany, New York. 